\title{
Decolorization and Mineralization of Batik Wastewater through Solar Photocatalytic Process
}

\author{
(Penyahwarnaan dan Penguraian Sisa Air Batik melalui Proses Fotopemangkinan Cahaya Matahari)
}

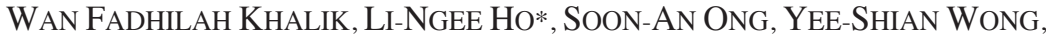 \\ NIK ATHIRAH YUSOFF \& FAHMI RIDWAN
}

\begin{abstract}
In this study, the photocatalytic degradation of batik wastewater in the presence of zinc oxide (ZnO) as photocatalyst was investigated. The effect of various operating parameters, such as $\mathrm{pH}$ of batik wastewater, catalyst dosage and aeration on the photocatalytic degradation process, was examined. The mineralization of batik wastewater was also evaluated through chemical oxygen demand analysis. The decolorization of batik wastewater was enhanced at acidic conditions (pH3) which was $88.2 \%$ after $10 \mathrm{~h}$ irradiated under solar light, meanwhile its mineralization was $286 \mathrm{mg} / \mathrm{L}$ after $12 \mathrm{~h}$ irradiation time. The data obtained for photocatalytic degradation of batik wastewater was well fitted with the LangmuirHinshelwood kinetic model. It can be concluded that batik wastewater could be decolorized and mineralized under solar light irradiation with presence of $\mathrm{ZnO}$.
\end{abstract}

Keywords: Batik wastewater; decolorization; mineralization; photocatalytic; zinc oxide

\section{ABSTRAK}

Di dalam kertas ini, degradasi sisa air batik oleh fotopemangkinan dengan kehadiran zink oksida sebagai fotopemangkin telah dikaji. Kesan daripada pelbagai parameter operasi, contohnya, pH sisa air batik, dos fotopemangkin dan pengudaraan ke atas proses fotopemangkinan telah dikaji. Penguraian sisa air batik juga dinilai melalui analisis permintaan oksigen kimia. Penyahwarnaan sisa air batik meningkat dalam keadaan berasid (pH3) iaitu $88.2 \%$ selepas 10 jam diradiasi di bawah cahaya matahari, sementara itu, penguraiannya ialah $286 \mathrm{mg} / \mathrm{L}$ selepas 12 jam masa penyinaran. Data yang diperoleh untuk degradasi fotopemangkinan sisa air batik adalah mengikut model kinetik Langmuir-Hinshelwood. Dapat disimpulkan bahawa sisa air batik boleh dinyahwarnakan dan diuraikan di bawah penyinaran cahaya matahari dengan kehadiran zink oksida.

Kata kunci: Fotopemangkinan; penguraian; penyahwarnaan; sisa air batik; zink oksida

\section{INTRODUCTION}

The textile industry such as batik industry consumes large amounts of discharged effluents during dyeing and finishing operations. Batik industries used many other chemical substances such as sodium silicate, sodium salt and sodium alginate. The discharged wastewater from textile industry is one of the most polluting among all industrial sectors such as pharmaceuticals, pulp and paper mill and paints (Gümüsş \& Akbal 2011). Besides, the wastewater from textile industry also contains other chemical substances which are not biodegradable and difficult to be removed by conventional treatment methods (Arslan \& Balcioglou 1999; Sun \& Yang 2003; Tsang et al. 2007). An acute exposure to the untreated wastewater containing dyes may cause severe problems such as jaundice, vomiting and increasing the heart rate (Hameed \& Ahmad 2009; Kitture et al. 2011).

Solar photocatalytic is one of the treatment methods under advanced oxidation processes (AOPs) which is low cost, environmental friendly and effective in treating wastewater. When solar light irradiation is equal or greater than the band gap energy of photocatalyst, an electron in the valence band will be excited out to the conduction band and leaves a hole in the valence band. The electron will combine with oxygen molecule to produce superoxide radical anions $\left(\cdot \mathrm{O}_{2}^{-}\right)$, meanwhile the hole in the valence band may react with water $\left(\mathrm{H}_{2} \mathrm{O}\right)$ or hydroxyl ions $\left(\mathrm{OH}^{-}\right)$ to generate the hydroxyl radicals $(\bullet \mathrm{OH})$. The $\bullet \mathrm{OH}$ and $-\mathrm{O}_{2}^{-}$are the primary oxidizing species in the photocatalytic processes.

Photocatalyst also plays crucial part in photocatalytic process. Most of previous researchers (Badawy et al. 2009; Tang \& Chen 2004) use $\mathrm{TiO}_{2}$ as their photocatalyst, however, $\mathrm{TiO}_{2}$ only show better performance under UV light irradiation. Other than that, $\mathrm{TiO}_{2}$ also is uneconomical for large scale water treatment operations (Shinde et al. 2011). Due to that reason, $\mathrm{ZnO}$ is found to be a suitable alternative to $\mathrm{TiO}_{2}$ since it has higher catalytic efficiency compared to $\mathrm{TiO}_{2}$ (Chakrabarti \& Dutta 2004; Daneshvar et al. 2004; Lin et al. 2011; Lizama et al. 2002). Moreover, $\mathrm{ZnO}$ also absorbs over a larger fraction of UV spectrum (Behnajady et al. 2006). Since Malaysia is one of the countries that 
has ample amount of solar light, it is suitable to use $\mathrm{ZnO}$ as a photocatalyst.

The objective of this study was to investigate the influence of various operating parameters on the decolorization and mineralization of batik wastewater under solar light irradiation with $\mathrm{ZnO}$ as a photocatalyst.

\section{MATERIALS AND METHODS}

Batik wastewater was collected in early January 2014 from batik workshop in Beseri, Perlis, Malaysia, at discharged point. The collected wastewater was preserved in the refrigerator. The characteristics of wastewater such as biochemical oxygen demand (BOD), chemical oxygen demand (COD), $\mathrm{pH}$, temperature, total suspended solid (TSS) and turbidity were analysed and the sample was then diluted by $1: 1$ using ultrapure water for further photocatalytic process. The photocatalyst used in this study was zinc oxide $(\mathrm{ZnO})$ which supplied by $\mathrm{HmBG}$ and its molecular weight was $81.37 \mathrm{~g} / \mathrm{mol}$. Acid sulfuric $\left(\mathrm{H}_{2} \mathrm{SO}_{4}\right)$ and sodium hydroxide $(\mathrm{NaOH})$ was used for $\mathrm{pH}$ adjustment.

The photocatalytic degradation of batik wastewater was conducted in a batch study under solar light irradiation and various operating parameters were examined. A beaker contains $250 \mathrm{~mL}$ of sample and diluted with 250 $\mathrm{mL}$ of ultrapure water was prepared for each experiment and placed on a magnetic stirrer. $0.1 \mathrm{~g}$ of $\mathrm{ZnO}$ was added into the solution and the reaction started. To evaluate the effect of $\mathrm{pH}$ of batik wastewater, its $\mathrm{pH}$ was varied to $\mathrm{pH} 3,7$ and 10. The dosage of $\mathrm{ZnO}$ also was differed to $0.05,0.10$ and $0.25 \mathrm{~g}$ for evaluating the effect of catalyst dosage on the degradation of batik wastewater. To evaluate the effect of aeration on the photocatalytic degradation of batik wastewater, air diffuser (Regent 9500) was used to supply aeration into the sample with $0.1 \mathrm{~g}$ of $\mathrm{ZnO}$ as a photocatalyst as shown in Figure 1. Experiments were conducted for $10 \mathrm{~h}$ and $15 \mathrm{~mL}$ of water samples were withdrawn with a syringe every $1 \mathrm{~h}$ of time interval $(0,1$, $2,3,4,5,6,7,8,9$ and $10 \mathrm{~h})$. Then, it was filtered with 125

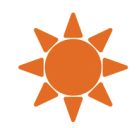

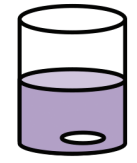

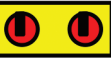

Without

aeration

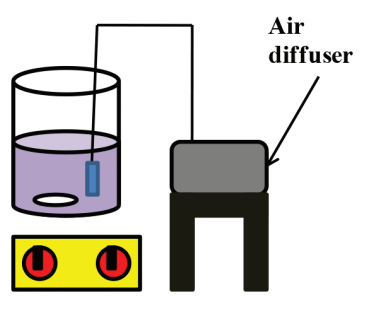

With aeration
FIGURE 1. Experimental set up for study the effect of aeration on decolorization of batik wastewater $\mathrm{mm}$ diameter of filter paper to remove the $\mathrm{ZnO}$ particles and the clear water was then analysed by UV-Vis spectrum. The DR2800 was used to analyse the concentration of BOD, COD and TSS of batik wastewater before and after the photocatalytic process.

\section{RESULTS AND DISCUSSION}

The batik wastewater sample was characterized in terms of the biochemical oxygen demand $\left(\mathrm{BOD}_{5}\right)$, chemical oxygen demand (COD), pH, temperature, total suspended solid (TSS) and turbidity. The characteristics of batik effluent were shown in Table 1 . The batik wastewater contained high value in all parameters especially COD concentration. This is in agreement with Şahinkaya (2013) who reported that most of the textile wastewater has high salinity, high $\mathrm{COD}$ and $\mathrm{pH}$ as well as strong color. Because of that, concentration of COD and color of batik or any textile wastewater need to be reduced before being discharged into water bodies.

TABLE 1. Characteristics of the batik effluent

\begin{tabular}{lc}
\hline Parameters & Value \\
\hline BOD $_{5}(\mathrm{mg} / \mathrm{L})$ & 341.25 \\
$\mathrm{COD}(\mathrm{mg} / \mathrm{L})$ & 4092 \\
$\mathrm{pH}$ & 10.77 \\
Temperature $\left({ }^{\circ} \mathrm{C}\right)$ & 25.3 \\
Turbidity $(\mathrm{NTU})$ & 217 \\
TSS $(\mathrm{mg} / \mathrm{L})$ & 303.03 \\
\hline
\end{tabular}

The UV-Vis absorption spectra of raw batik wastewater showed absorption peaks at $232 \mathrm{~nm}$ and $516 \mathrm{~nm}$ as in Figure 2. The peak appeared in visible region $(516 \mathrm{~nm})$ indicated the existence of chromophore that is responsible in giving color to the batik wastewater meanwhile peak in UV region $(232 \mathrm{~nm})$ showed the aromatic ring that attached to the molecular structure of the batik wastewater.

Batik wastewater has a high $\mathrm{pH}$ value. Batik wastewater sample which collected had a $\mathrm{pH}$ of 10.77 . $\mathrm{pH}$ played a crucial role in photocatalytic processes due to its influence towards the production of $\bullet \mathrm{OH}$. In order to study the influence of $\mathrm{pH}$ towards batik wastewater, $\mathrm{pH}$ was adjusted to $\mathrm{pH} 3,7$ and 10 (unadjusted). The removal efficiency of batik wastewater at pH3, 7 and 10 was 88.2, 86.9 and $67.6 \%$, respectively, after $10 \mathrm{~h}$ irradiation time as shown in Figure 3(a). The degradation rate of batik wastewater increased in acidic phase due to relation of acid base property of the metal oxide surface which can be explained by the basis of zero point charge (Kansal et al. 2007). The zero point charge (zpc) of $\mathrm{ZnO}$ was 9.00.3. The surface of $\mathrm{ZnO}$ was positively charged below pH9 and negatively charged above that $\mathrm{pH}$. Therefore, acidic conditions such as in this case at $\mathrm{pH} 3$ would favor the electrostatic attraction between positively charged $\mathrm{ZnO}$ surface and the dye, which then increased the decolorization of batik wastewater (Gümüş \& Akbal 2011). 


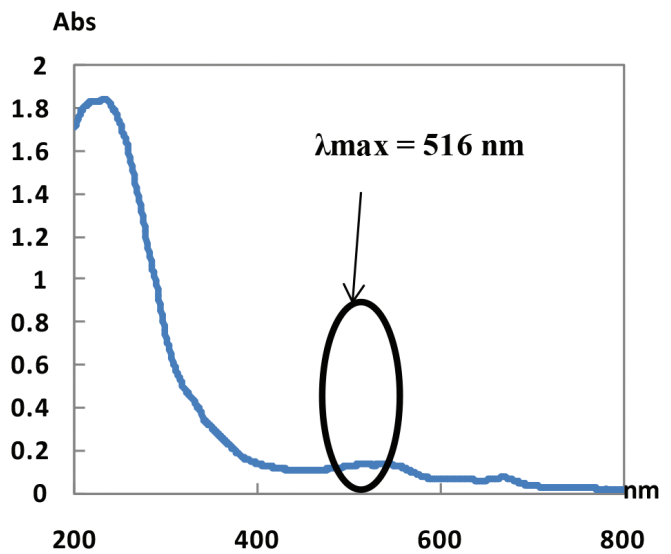

FIGURE 2. UV-Vis spectrum analysis of raw batik wastewater

Most of authors have used the modified LangmuirHinshelwood kinetic expression to analyse the heterogeneous photocatalytic reaction (Velmurugan \& Swaminathan 2011; Vineetha et al. 2013; Zhu et al. 2009). Figure 3(b) depicts plots of $\ln \mathrm{C}_{\mathrm{o}} / \mathrm{C}$ against solar light irradiation time at three $\mathrm{pHs}$ of batik wastewater. The decolorization of batik wastewater at different $\mathrm{pH}$ followed Langmuir-Hinshelwood kinetic model. The rate constant decreased as the $\mathrm{pH}$ of batik wastewater increased. The pseudo-first-order rate constant of $\mathrm{pH} 3,7$ and 10 was $0.304,0.239$ and $0.118 \mathrm{~h}^{-1}$, respectively. At low $\mathrm{pH}$ or in acidic phase, these positive holes can react with $\mathrm{OH}^{-}$or $\mathrm{H}_{2} \mathrm{O}$ and oxidized them to form $\bullet \mathrm{OH}$, thus increased the photocatalytic process. On the other hand, in alkaline phase, there was a Coulombic repulsion between the $\mathrm{OH}^{-}$ and negative charged surface of $\mathrm{ZnO}$ which could prevent the formation of $\bullet \mathrm{OH}$ and then resulted in decreased of decolorization rate of batik wastewater (Habibi \& Askari 2011).

Catalyst dosage is another important parameter in the photocatalytic treatment of dye. Three different amount of $\mathrm{ZnO}(0.05,0.1,0.25 \mathrm{~g})$ was added into the batik wastewater for the treatment. As shown in Figure 4, the maximum removal efficiency was $91.9 \%$ at $\mathrm{ZnO}$ dosage of $0.25 \mathrm{~g}$ after $10 \mathrm{~h}$ irradiation time. Meanwhile, the removal efficiency for $\mathrm{ZnO}$ dosage of 0.1 and $0.05 \mathrm{~g}$ was 88.2 and $75.3 \%$, respectively, at the same irradiation time. There was a significant positive correlation between catalyst dose and color removal efficiency. The result showed that increasing amount of $\mathrm{ZnO}$ dosage will increase removal efficiency of wastewater. The differences of removal efficiency between $\mathrm{ZnO}$ dosage of 0.1 and $0.25 \mathrm{~g}$ was only $3.7 \%$ and because of this reason, for other parameters in this research, $0.1 \mathrm{~g}$ of $\mathrm{ZnO}$ dosage was used as an optimum catalyst dosage. It was well known that excess dosage of photocatalyst would reflect back the solar light irradiation by catalyst particles (Krishnakumar \& Swaminathan 2011). At lower catalyst dosage, the total surface area of active site which was available for interaction between dye and catalyst would be limited, hence decreased the efficiency of color to be removed (Akyol \& Bayramoğlu 2005). On the contrary, increasing the catalyst dosage will increase the available surface of the catalyst and which in turn increase the reactive sites for generation of active radicals such as $\bullet \mathrm{O}_{2}$ and $\bullet \mathrm{OH}$ and then, enhanced the removal efficiency of batik wastewater.

The study of removal of Acid Orange 7 from aqueous solution by UV irradiation in the presence of $\mathrm{ZnO}$ nanopowder was carried out by Daneshvar et al. (2007) found that the photodegradation efficiency increased with an increase in $\mathrm{ZnO}$ nanopowder concentration. Akyol et al. (2004) examined the effect of $\mathrm{ZnO}$ loading in decolorization of Remazol Red RR and found that decolorization efficiency of Remazol Red RR increased by increasing the catalyst loading.

The photodegradation of batik wastewater was conducted under the condition of with and without aeration. The removal efficiency of batik wastewater with aeration after $10 \mathrm{~h}$ irradiated under solar light achieved $71.1 \%$ as shown in Figure 5. However, in the case of without aeration, only $50.8 \%$ of batik wastewater could be decolorized. The

(a)
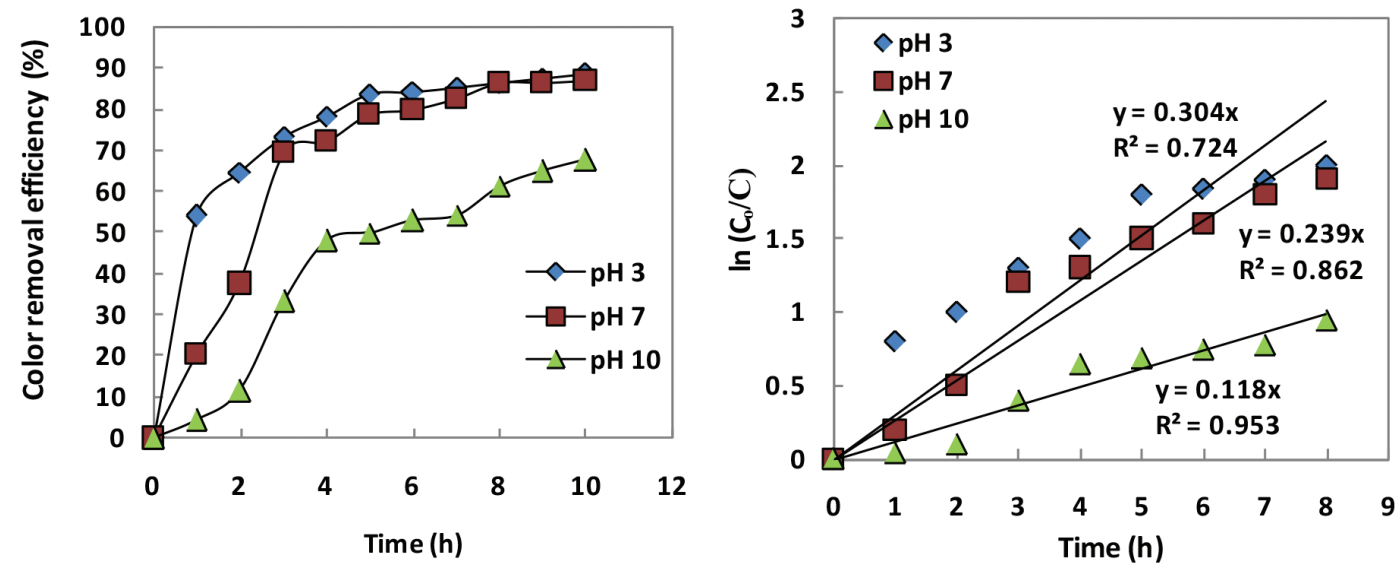

FIGURE 3. (a) Color removal efficiency and (b) plot of $\ln \mathrm{C}_{0} / \mathrm{C}$ against irradiation time for different $\mathrm{pH}$ of batik wastewater 


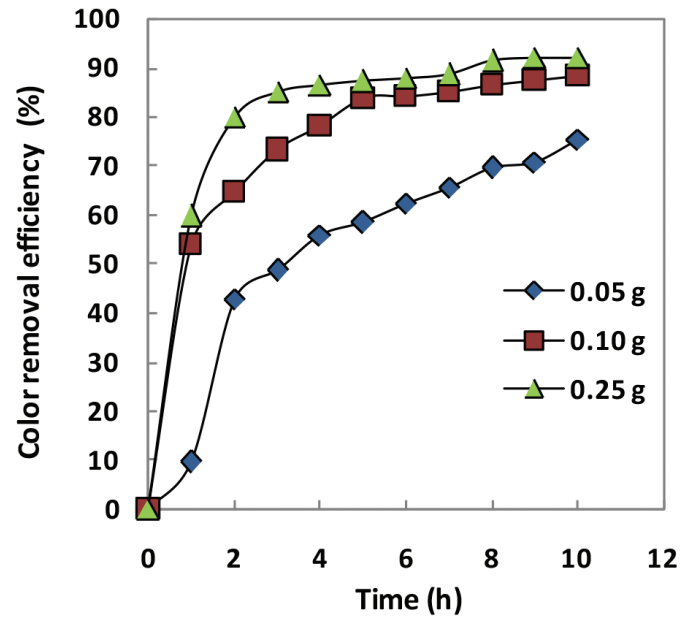

FIGURE 4. Removal efficiency of batik wastewater at different $\mathrm{ZnO}$ dosage

presence of oxygen enhanced photocatalytic degradation since it will react with conduction band electrons in order to form superoxide radical anions which eventually yield reactive $\bullet \mathrm{OH}$ (Fotiadis et al. 2007). The oxygen supplied into the batik wastewater could prevent the recombination between electron and hole which would reduce the photocatalytic activity (Nishio et al. 2006). As the $\mathrm{ZnO}$ irradiated by solar light, an electron is excited out of its energy level to conduction band and leaves a positive hole in the valence band. The positive hole is a strong oxidant which can either react with electron donors like $\mathrm{OH}^{-}$or $\mathrm{H}_{2} \mathrm{O}$ to form $\bullet \mathrm{OH}$ or oxidize the azo dye directly. Meanwhile, the excited electron can be trapped by oxygen molecules from air bubbling to form ${ }^{-\mathrm{O}_{2}}$ - on the surface of $\mathrm{ZnO}$. Thus, the photocatalytic degradation can be enhanced due to the formation of more oxygen active species in the wastewater.

The complete decolorization of batik wastewater can be analyzed using UV-Vis spectrum. The reduction in absorption peak $\left(\lambda_{\max }\right)$ at $516 \mathrm{~nm}$ of batik wastewater was

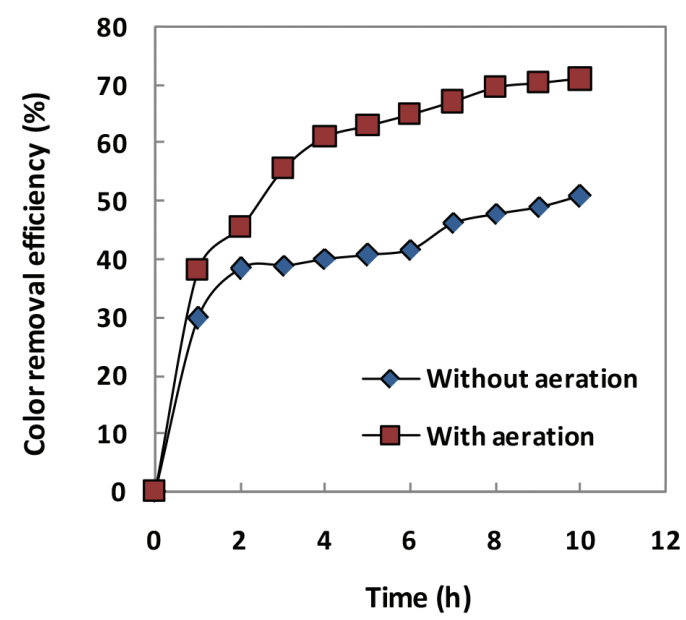

FIGURE 5. Removal efficiency of batik wastewater in with and without aeration shown in Figure 6. Within $10 \mathrm{~h}$ of solar light irradiation, batik wastewater achieved almost $100 \%$ of color removal. The disappearance rate at maximum wavelength (516 $\mathrm{nm}$ ) in visible region rapidly decreased compared to the maximum wavelength $(232 \mathrm{~nm})$ in the UV region. There was only slightly removal efficiency in aromatic compounds which is in UV region after $10 \mathrm{~h}$ irradiated under solar light. The generation of $\bullet \mathrm{OH}$ from photocatalytic reaction attacked the azo bond linkage $(-\mathrm{N}=\mathrm{N}-)$ which resulting in decolorization of batik wastewater. The broken down of azo bond linkage increased the generation of aromatic and naphthalene compounds. The solar photocatalytic process cannot completely mineralize the intermediate products due to the combination of batik wastewater with other substances such as sodium silicate in dyeing and washing processes.

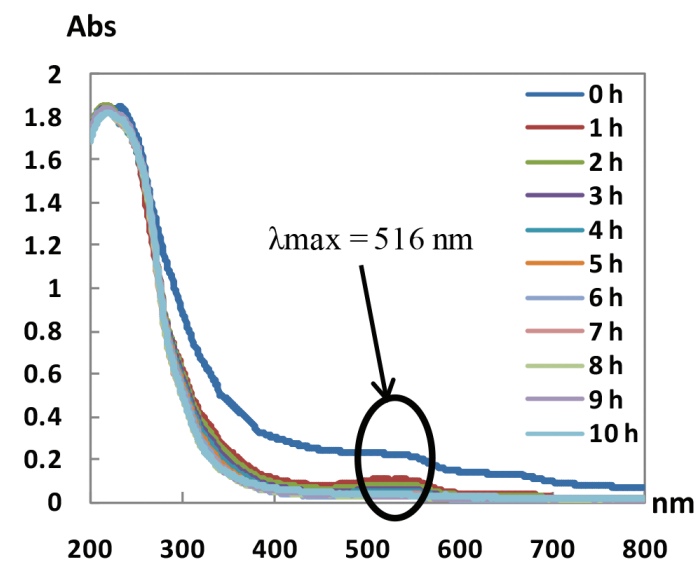

FIGURE 6. UV-Vis spectrum analysis of batik wastewater

The wastewater sample placed under direct solar light irradiation for $12 \mathrm{~h}$ to analyse its COD. The initial COD concentration of wastewater was $1332 \mathrm{mg} / \mathrm{L}$ and after 12 $\mathrm{h}$ irradiation time, its COD concentration decreased until $286 \mathrm{mg} / \mathrm{L}$ as shown in Figure 7. This result indicated that the degradation of batik wastewater occurred until $12 \mathrm{~h}$ solar irradiated. The decreased in COD concentration of batik wastewater was along with its removal efficiency. Although the COD concentration does not achieved the Seventh Schedule for Standard A and B as showed in Table 2 , however, based on the results, the COD concentration could be reduced by extending the irradiation time up to $24 \mathrm{~h}$. The $\bullet \mathrm{OH}$ generated from interaction between $\mathrm{ZnO}$ and solar light irradiation will attack the azo bond linkage $(-\mathrm{N}=\mathrm{N}-)$ of dye molecules and break down them to form nitrate and nitrite. The $\bullet \mathrm{OH}$ then break down the benzene and naphthalene ring and formed intermediate products. The partially mineralization of batik wastewater after $12 \mathrm{~h}$ irradiated under solar light would produce $\mathrm{CO}_{2}, \mathrm{NO}_{3}^{-}, \mathrm{Na}^{+}$, $\mathrm{SO}_{4}{ }^{2-}, \mathrm{H}_{2} \mathrm{O}, \mathrm{H}^{+}$and $\mathrm{Cl}^{-}$. Krishnakumar and Swaminathan (2011) in their study reported that the COD value of dye decreased after $1 \mathrm{~h}$ irradiation time. 


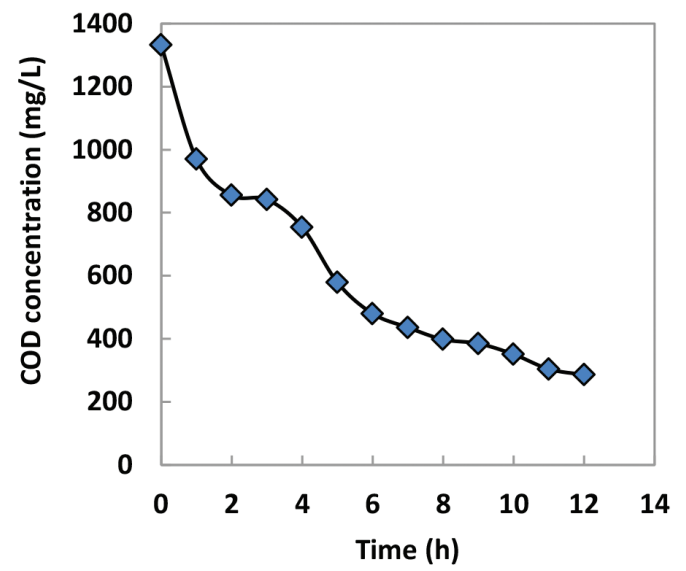

FIGURE 7. COD concentration of batik wastewater after $12 \mathrm{~h}$ irradiation time

TABLE 2. Seventh Schedule (Regulation 12) for COD in industry sector

\begin{tabular}{|c|c|c|c|c|}
\hline & Trade/Industry & Unit & Standard & Standard \\
\hline & (1) & (2) & (3) & (4) \\
\hline (a) & Pulp and paper industry & & & 350 \\
\hline & (i) Pulp mill & $\mathrm{mg} / \mathrm{L}$ & 80 & 250 \\
\hline & (ii) Paper mill (recycled) & $\mathrm{mg} / \mathrm{L}$ & 80 & 300 \\
\hline & (iii) Pulp and paper mill & $\mathrm{mg} / \mathrm{L}$ & 80 & \\
\hline (b) & Textile industry & $\mathrm{mg} / \mathrm{L}$ & 80 & 250 \\
\hline (c) & Fermentation and distillery industry & $\mathrm{mg} / \mathrm{L}$ & 400 & 400 \\
\hline (d) & Other industries & $\mathrm{mg} / \mathrm{L}$ & 80 & 200 \\
\hline
\end{tabular}

After the degradation of batik wastewater by solar photocatalytic process under optimized conditions $(0.1 \mathrm{~g}$ of $\mathrm{ZnO}$ and operating $\mathrm{pH}$ of 3.00 ), the characterization of batik wastewater was evaluated. Table 3 shows the parameters which had been analyzed after $10 \mathrm{~h}$ irradiated by solar light. The results showed significant removal efficiency of the major parameters especially in COD. The removal efficiency of $\mathrm{BOD}_{5}, \mathrm{COD}$, turbidity and TSS was $52,91,54$ and $74 \%$, respectively. Other than decolorization of batik wastewater, its biodegradability also can be determined by the ratio of $\mathrm{BOD}_{5} / \mathrm{COD}$. The ratio of $\mathrm{BOD}_{5} / \mathrm{COD}$ of batik wastewater within $10 \mathrm{~h}$ of solar light irradiation was 0.5 , however, the ratio of $\mathrm{BOD}_{5} / \mathrm{COD}$ of batik wastewater before treatment was 0.08 . The batik wastewater has the ratio of $\mathrm{BOD}_{5} / \mathrm{COD}$ higher than 0.3 where indicated that it has better biodegradability.

\section{CONCLUSION}

Photocatalytic degradation using $\mathrm{ZnO}$ was successfully applied for the decolorization and mineralization of batik wastewater under solar light irradiation. The results indicated that the removal efficiency of batik wastewater was obviously affected by the photocatalyst dosage, $\mathrm{pH}$ and aeration. The decolorization of batik wastewater was increased significantly by increasing the amount of $\mathrm{ZnO}$. The results also indicated that the decolorization of batik wastewater was faster than its mineralization. The removal efficiency of batik wastewater at optimum condition (pH3 and $0.1 \mathrm{~g}$ of $\mathrm{ZnO}$ ) was $88.2 \%$ during 10 $\mathrm{h}$ irradiation time. The decolorization of batik wastewater followed pseudo-first-order rate constant of LangmuirHinshelwood kinetic model. The mineralization of batik

TABLE 3. Characteristics of batik wastewater after photocatalytic activity

\begin{tabular}{lcc}
\hline Parameters & Value & Removal efficiency $(\%)$ \\
\hline $\mathrm{BOD}_{5}(\mathrm{mg} / \mathrm{L})$ & 164.56 & 52 \\
$\mathrm{COD}(\mathrm{mg} / \mathrm{L})$ & 351 & 91 \\
$\mathrm{pH}$ & 3.21 & - \\
Temperature $\left({ }^{\circ} \mathrm{C}\right)$ & 25.3 & - \\
Turbidity $(\mathrm{NTU})$ & 99 & 54 \\
TSS $(\mathrm{mg} / \mathrm{L})$ & 80 & 74 \\
\hline
\end{tabular}


wastewater through COD analysis achieved $286 \mathrm{mg} / \mathrm{L}$ after $12 \mathrm{~h}$ irradiation time.

\section{REFERENCES}

Akyol,A. \& Bayramoğlu, M. 2005. Photocatalytic degradation of Remazol Red F3B using ZnO catalyst. Journal of Hazardous Materials B124: 241-246.

Akyol,A., Yatmaz, H.C. \& Bayramoğlu, M. 2004. Photocatalytic decolorization of Remazol Red RR in aqueous $\mathrm{ZnO}$ suspensions. Applied Catalysis B: Environmental 54: 19-24.

Arslan, I. \& Balcioglou, I.A. 1999. Degradation of commercial reactive dyestuffs by heterogeneous and homogenous advanced oxidation processes: A comparative study. Dyes Pigments 43: 95-108.

Badawy, M.I., Gohary, F.E., Ghaly, M.Y. \& Ali, M.E.M. 2009. Enhancement of olive mill wastewater biodegradation by homogeneous and heterogeneous photocatalytic oxidation. Journal of Hazardous Materials 169: 673-679.

Behnajady, M.A., Modirshahla, N. \& Hamzavi, R. 2006. Kinetic study on photocatalytic degradation of C.I. Acid Yellow 23 by $\mathrm{ZnO}$ photocatalyst. Journal of Hazardous Materials B133: 226-232.

Chakrabarti, S. \& Dutta, B.K. 2004. Photocatalytic degradation of model textile dyes in wastewater using $\mathrm{ZnO}$ as semiconductor catalyst. Journal of Hazardous Materials B112: 269-278.

Daneshvar, N., Rasoulifard, M.H., Khataee,A.R.\& Hosseinzadeh, F. 2007. Removal of C.I. Acid Orange 7 from aqueous solution by UV irradiation in the presence of $\mathrm{ZnO}$ nanopowder. Journal of Hazardous Materials 143: 95-101.

Daneshvar, N., Salari, D. \& Khataee, A.R. 2004. Photocatalytic degradation of azo dye acid red 14 in water on $\mathrm{ZnO}$ as an alternative catalyst to $\mathrm{TiO}_{2}$. Journal of Photochemistry and Photobiology A: Chemistry 162: 317-322.

Fotiadis, C., Xekoukoulotakis, N.P. \& Mantzavinos, D. 2007. Photocatalytic treatment of wastewater from cottonseed processing: Effect of operating conditions, aerobic biodegradability and ecotoxicity. Catalysis Today 124: 247-253.

Gümüş, D. \& Akbal, F. 2011. Photocatalytic degradation of textile dye and wastewater. Water Air Soil Pollution 216: 117-124.

Habibi, M.H. \& Askari, E. 2011. Photocatalytic degradation of an azo textile dye with manganese-doped $\mathrm{ZnO}$ nanoparticles coated on glass. Iranian Journal of Catalysis 1: 41-44.

Hameed, B.H. \& Ahmad, A.A. 2009. Batch adsorption of methylene blue from aqueous solution by garlic peel an agricultural waste biomass. Journal of Hazardous Materials 164: 870-875.

Kansal, S.K., Singh, M. \& Sud, D. 2007. Studies on photodegradation of two commercial dyes in aqueous phase using different photocatalysts. Journal of Hazardous Materials 141(3): 581-590.

Kitture, R., Koppikar, S.J., Kaul-Ghanekar, R. \& Kale, S.N. 2011. Catalyst efficiency, photostability and reusability study of $\mathrm{ZnO}$ nanoparticles in visible light for dye degradation. Journal of Physics and Chemistry of Solids 72: 60-66.

Krishnakumar, B. \& Swaminathan, M. 2011. Influence of operational parameters on photocatalytic degradation of a genotoxic azo dye Acid Violet 7 in aqueous $\mathrm{ZnO}$ suspensions. Spectrochimica Acta Part A 81: 739-744.

Lin, W., Yan, X., Zhang, X., Qin, Z., Zhang, Z., Bai, Z., Lei, Y. \& Zhang, Y. 2011. The comparison of ZnO nanowire detectors working under two wavelengths of ultraviolet. Solid State Communications 151: 1860-1863.

Lizama, C., Freer, J., Baeza, J. \& Mansilla, H.D. 2002 . Optimized photodegradation of Reactive Blue 19 on $\mathrm{TiO}_{2}$ and $\mathrm{ZnO}$ suspensions. Catalysis Today 76: 235-246.

Nishio, J., Tokumura, M., Znad, H.T. \& Kawase, Y. 2006. Photocatalytic decolorization of azo-dye with zinc oxide powder in an external UV light irradiation slurry photoreactor. Journal of Hazardous Materials B138: 106-115.

Şahinkaya, S. 2013. COD and color removal from synthetic textile wastewater by ultrasound assisted electro-Fenton oxidation process. Journal of Industrial and Engineering Chemistry 19: 601-606.

Shinde, S.S., Shinde, P.S., Bhosale, C.H. \& Rajpure, K.Y. 2011. Zinc oxide mediated heterogeneous photocatalytic degradation of organic species under solar radiation. Journal of Photochemistry and Photobiology B: Biology 104: 425433.

Sun, Q. \& Yang, L. 2003. The adsorption of basic dyes from aqueous solution on modified peat-resin particle. Water Research 37: 1535-1544.

Tang, C. \& Chen, V. 2004. The photocatalytic degradation of reactive black 5 using $\mathrm{TiO}_{2} / \mathrm{UV}$ in an annular photoreactor. Water Research 38: 2775-2781.

Tsang, D.C.W., Hu, J., Liu, M.Y., Zhang, W., Lai, K.C.K. \& Lo, I.M.C. 2007. Activated carbon produced from waste wood pallets: Adsorption of three classes of dyes. Water Air Soil Pollution 184: 141-155.

Velmurugan, R. \& Swaminathan, M. 2011. An efficient nanostructured $\mathrm{ZnO}$ for dye sensitized degradation of Reactive Red 120 dye under solar light. Solar Energy Materials \& Solar Cells 95: 942-950.

Vineetha, M.N., Matheswaran, M. \& Sheeba, K.N. 2013. Photocatalytic colour and COD removal in the distillery effluent by solar radiation. Solar Energy 91: 368-373.

Zhu, H., Jiang, R., Xiao, L., Chang, Y., Guan, Y., Li, X. \& Zeng, G. 2009. Photocatalytic decolorization and degradation of Congo Red on innovative crosslinked chitosan/nano-CdS composite catalyst under visible light irradiation. Journal of Hazardous Materials 169: 933-940.

Wan Fadhilah Khalik, Soon-An Ong, Yee-Shian Wong, Nik Athirah Yusoff \& Fahmi Ridwan

Water Research Group

School of Environmental Engineering

Universiti Malaysia Perlis

02600 Arau, Perlis

Malaysia

Li-Ngee Ho*

School of Material Engineering

Universiti Malaysia Perlis

02600 Arau, Perlis

Malaysia

*Corresponding author; email: 1nho@unimap.edu.my

Received: 26 September 2014

Accepted: 3 December 2014 